Pak. j. sci. ind. res. Ser. B: biol. sci. 2016 59(3) 146-154

\title{
The Influence of Storage of Pawpaw Carica papaya Fruit on the Bioactive Components, Antioxidative Properties and Inhibition of $\mathrm{Fe}^{2+}$-Induced Lipid Peroxidation of Water-Extracts of Pawpaw Seed
}

\author{
Foluso Olutope Adetuyi*, Abimbola Olawumi Iroaye, Olamide Muyiwa Babatunde \\ and Gloria Jacinta Effiong \\ Biochemistry Unit, Chemical Sciences Department, Ondo State University of Science and Technology, \\ PMB 353, Okitipupa, Ondo State, Nigeria
}

(received August 25, 2015; revised February 16, 2016; accepted March 17, 2016)

\begin{abstract}
Freshly harvested, matured, newly ripe pawpaw (Carica papaya) fruit (Maradol variety) was stored at room temperature $\left(27 \pm 1^{\circ} \mathrm{C}\right)$ for 7 days. The seeds of the freshly harvested and stored pawpaw fruit were taken and divided into two groups each; one was dried as dry sample, dry freshly harvested sample (DFHS) and dry stored sample (DSS) while the other was left as wet sample, wet freshly harvested sample (WFHS) and wet stored sample (WSS). The bioactive components, antioxidative properties and inhibition of $\mathrm{Fe}^{2+}$ induced lipid peroxidation activity of the water extract of the seed were investigated. Storage of pawpaw fruit caused a significant increase in ascorbic acid and flavonoid content of the pawpaw seed in both dry and wet samples but only in dry stored sample significant increase in the phenol content of the seed was observed. The dried pawpaw seed DFHS and DSS showed stronger inhibition of $\mathrm{Fe}^{2+}$ induced lipid peroxidation activities.
\end{abstract}

Keywords: pawpaw seed, storage influence, phenol, ascorbic acid, flavonoid, DPPH scavenging ability, lipid peroxidation

\section{Introduction}

Pawpaw (Carica papaya) is a small tropical tree native to South America. It normally grows with a single and branched trunk which may reach $10 \mathrm{~m}$ in height but is more commonly 4-5 $\mathrm{m}$ tall. The pawpaw plant is widely spread throughout tropical Africa. It belongs to the group Caricaceae (Adetuyi et al., 2008). The skin colour of pawpaw fruit is usually green when immature, changing to fully reddish-orange or yellow-orange when fully ripened. The changes in the outer colour of the fruit skin is an indication of ripeness, and this change is considered mainly due to an increase in the carotene content and a decrease in chlorophyll (Maisarah et al., 2014). In the early stages of fruit development, the main sugar in pawpaw is glucose. There is an increase in sucrose content of pawpaw fruit during ripening which can be up to $80 \%$ of the total sugars. The crude protein content has been reported to range from 3.74-8.26 g/ $100 \mathrm{~g}$ dry matter while aspartic and glutamic acid are the most abundant amino acids in ripe fruits (Saran and Choudhary, 2013).

The central cavity of pawpaw fruit contains large quantities of seeds that are small, black, round, covered *Author for correspondence; E-mail: foluadetuyi@yahoo.co.uk with gelatinous aril and make up about $15 \%$ of the wet weight of the fruit (Malacrida et al., 2011; Afolabi and Ofobrukweta, 2011). Several studies revealed that pawpaw seeds are a rich source of proteins (27.3-28.3\%), lipids (28.2-30.7\%), and crude fibres (19.1-22.6\%). Also it contains appreciable quantities of calcium and phosphorus (Malacrida et al., 2011). In pawpaw seed the enzyme carpesemine is a plant growth inhibitor and oleanolic glycoside is an agent of sterility in male albino rats. Alkaloids have been reported in the endosperm of pawpaw seed. Fatty acids such as oleic, palmitic, stearic and linoleic acid have been found in pawpaw seed (Bolu et al., 2009). It has been discovered that glutamic acid, arginine, proline, and aspartic acid are present in the endosperm of pawpaw seed while proline, tyrosine, lysine, aspartic acid and glutamic acid are found in the sarcotesta (Saran and Choudhary, 2013).

Pawpaw latex, shoot, leaves, fruits and seeds contain a broad spectrum of phytochemicals including enzymes, carotenoids, alkaloids, phenolics, and glucosinolates. People in Lao, Cambodia, and Vietnam use the latex to treat eczema and psoriasis. The seeds have been used as vermifuge, thirst quencher, or pain alleviator (Krishna et al., 2008; Amenta et al., 2000). Phenolic compounds 
in pawpaw fruit peel and seeds have antioxidative properties (Ang et al., 2012). The seed of pawpaw has antimicrobial activity against Trichomonas vaginalis trophozoites. The seeds, irrespective of its fruit maturity stages have bacteriostatic activity on gram positive and gram negative organisms which could be useful in treating chronic skin ulcer (Afolabi and Ofobrukweta, 2011).

Pawpaw seed has shown clearly to have antihelminthic, immunomodulatory activities and having anti-amoebic properties; they are also rich source of amino acids especially in the sarcotesta. Air dried papaya seeds with honey showed significant effect on human intestinal parasites without significant side effect (Saran and Choudhary, 2013; Okeniyi et al., 2007). The pawpaw seed extract has shown to possess gastro-protective effect on ethanol induced gastric ulcer in rats and also used in treatment of sickle cell disease (Saran and Choudhary, 2013; Okewumi and Oyeyemi, 2012). Seeds of overripe pawpaw fruit are good source of protein, energy, nutritive minerals and have low antinutrient values (Oyeleke et al., 2013).

There has been no previous study to directly compare bioactive contents and antioxidant properties of pawpaw seed, with respect to storage of pawpaw fruit. Therefore, the aim of this study was to determine the effect of storage of pawpaw fruit at room temperature on the bioactive content and antioxidant properties of pawpaw seed.

\section{Materials and Methods}

Materials. The maturity stages of the pawpaw used in this study were evaluated visually based on the skin colour as defined by Hana and Angelo (2006): Stage 0 - totally green; Stage 1 - yellow colour that does not cover more than $15 \%$ of skin surface; Stage 2 - fruit with $16-25 \%$ of yellow skin; Stage 3 - fruit with $26-50 \%$ of yellow skin. Freshly harvested, matured, newly ripe pawpaw fruit (Maradol variety) stage 1 with slight appearance of yellow colour obtained from Ondo State University of Science and Technology farm was used for this study.

Reagents. Ascorbic acid was from Merck (Darmstadt, Germany), gallic acid and quercetin were from Aldrich (Steinheim Germany), 1,1-diphenyl-2 picrylhydrazyl (DPPH), 1,10 orthophenanthroline, trichloroacetic acid (TCA) and potassium ferricyanide were obtained from Sigma Chemical Inc. (St Louis, MO, USA). Glass-distilled water and analytical grade chemicals and solvent were used in the present study.
Sample preparation. The freshly harvested pawpaw fruit was stored at room temperature $\left(27 \pm 1^{\circ} \mathrm{C}\right)$ for 7 days. The seed of the freshly harvested and stored pawpaw fruit (200 g each) were taken and divided into two groups; one was dried in the oven at $45^{\circ} \mathrm{C}$ for 5 days as dry sample, dry freshly harvested sample (DFHS) and dry stored sample (DSS) while the other was left as wet sample, wet freshly harvested sample (WFHS) and wet stored sample (WSS). The ascorbic acid, total phenol, flavonoid, ABTS scavenging ability, ferric reducing antioxidant property (FRAP), $\mathrm{Fe}^{2+}$ chelation assay, DPPH free radical scavenging ability and lipid peroxidation of the dry and wet samples were determined. All determinations were done in triplicates.

Aqueous extract preparation. The aqueous extracts of pawpaw seeds was prepared using a modified procedure described by Oboh et al. (2010). Ten grams $(10 \mathrm{~g})$ of the dry pawpaw seed and wet pawpaw seed were separately homogenised in $100 \mathrm{~mL}$ distilled water in a Warring blender. The homogenate was centrifuged at $4500 \mathrm{~g}$ for $15 \mathrm{~min}$. The supernatant was used for the determination of the bioactive content and antioxidant properties of pawpaw seed.

Ascorbic acid content determination. The ascorbic acid content of the aqueous extract was determined using the method of Benderitter et al. (1998). $75 \mu \mathrm{L}$ DNPH (2 g dinitrophenyl hydrazine, $230 \mathrm{mg}$ thiourea and $270 \mathrm{mg} \mathrm{CuSO}_{4} .5 \mathrm{H}_{2} \mathrm{O}$ in $100 \mathrm{~mL}$ of $5 \mathrm{~mL} \mathrm{H}_{2} \mathrm{SO}_{4}$ ) was added to $500 \mu \mathrm{L}$ extracts mixture $(300 \mu \mathrm{L}$ of an appropriate dilution of the extract with $100 \mu \mathrm{L} 13.3 \%$ trichloroacetic acid (TCA and water). The reaction mixture was subsequently incubated for $3 \mathrm{~h}$ at $37^{\circ} \mathrm{C}$, then $0.5 \mathrm{~mL}$ of $65 \% \mathrm{H}_{2} \mathrm{SO}_{4}(\mathrm{v} / \mathrm{v})$ was added to the medium and the absorbance was measured at $520 \mathrm{~nm}$ in a spectrophotometer (JENWAY 6305). The vitamin $\mathrm{C}$ content of the extracts was subsequently calculated using ascorbic acid as standard.

Phenolic content determination. The total phenol content was determined according to the method of Singleton et al. (1999). Appropriate dilutions of the extracts were mixed with $2.5 \mathrm{~mL}$ of $10 \%$ FolinCiocalteau's reagent (v/v) and neutralised by $2.0 \mathrm{~mL}$ of $7.5 \%$ sodium carbonate. The reaction mixture was incubated for $40 \mathrm{~min}$ at $45^{\circ} \mathrm{C}$ and the absorbance was measured at $765 \mathrm{~nm}$ in a spectrophotometer (JENWAY 6305). The total phenol content was subsequently calculated using gallic acid as standard. 
Flavonoid content determination. The total flavonoid content of the extracts was determined using a slightly modified method reported by Meda et al. (2005). Briefly, $0.5 \mathrm{~mL}$ of appropriately diluted sample was mixed with $0.5 \mathrm{~mL}$ methanol, $50 \mathrm{~mL}$ of $10 \%$ aluminium chloride $\left(\mathrm{AlCl}_{3}\right), 50 \mathrm{~mL}$ of $1 \mathrm{~mol} / \mathrm{L}$ potassium acetate and 1.4 $\mathrm{mL}$ water, and allowed to incubate at room temperature for $30 \mathrm{~min}$. Thereafter, the absorbance of the reaction mixture was subsequently measured at $415 \mathrm{~nm}$ using a spectrophotometer (JENWAY 6305). The total flavonoid was calculated using quercetin as standard.

Ferric reducing antioxidant power (FRAP). The reducing property of the extracts was determined by assessing the ability of the extract to reduce $\mathrm{FeCl}_{3}$, solution as described by Oyaizu (1986). A $2.5 \mathrm{~mL}$ aliquot was mixed with $2.5 \mathrm{~mL}$ of $200 \mathrm{mM}$ sodium phosphate buffer (pH 6.6) and $2.5 \mathrm{~mL}$ of $1 \%$ potassium ferricyanide. The mixture was incubated at $50{ }^{\circ} \mathrm{C}$ for $20 \mathrm{~min}$; thereafter $2.5 \mathrm{~mL}$ of $10 \%$ trichloroacetic acid was added. This mixture was centrifuged at $2000 \mathrm{~g}$ for $10 \mathrm{~min} ; 5 \mathrm{~mL}$ of the supernatant was mixed with an equal volume of water and $1 \mathrm{~mL}$ of $0.1 \%$ ferric chloride. The absorbance was measured at $700 \mathrm{~nm}$ in a spectrophotometer (JENWAY 6305) and ferric reducing antioxidant property was subsequently calculated using ascorbic acid as standard.

Iron chelating activity. Iron chelating activity was determined according to the method of Kuda et al. (2005). The pawpaw sample solution $(0.1 \mathrm{~mL})$ was taken into $10 \mathrm{~mL}$ test tube, $0.1 \mathrm{~mL}$ of distilled water and $0.025 \mathrm{~mL}$ of $2.5 \mathrm{mM}$ iron chloride were added, it was thoroughly shaken and the absorbance was taken at $550 \mathrm{~nm}$ (Abs1). $0.025 \mathrm{~mL}$ of $2.5 \mathrm{mM}$ ferrozine was added to the mixture, it was allowed to stay for $20 \mathrm{~min}$ at room temperature; the absorbance was taken at 550 $\mathrm{nm}(\mathrm{Abs} 2)$.

DPPH free radical scavenging ability. The free radical scavenging ability of the extract was determined using 1, 1-diphenyl-2-picryl hydrazyl (DPPH) as described by Singh et al. (2002). Different concentrations of the aqueous extract were taken in different test tubes and the volume was prepared to $1 \mathrm{~mL}$ with distilled water. $4 \mathrm{~mL}$ of $0.1 \mathrm{mM}$ methanolic solution of DPPH was added. The tubes were shaken vigorously and allowed to stand for $20 \mathrm{~min}$ at room temperature. A control was prepared as above without the sample and distilled water was used for base line correction. Changes in absorbance of samples were measured at $517 \mathrm{~nm}$ in a spectrophotometer (JENWAY 6305). Free radical scavenging activity was expressed as percentage inhibition and was calculated using the following formula:

Free radical scavenging activity $(\%)=($ control OD - sample OD)/control OD $\times 100$

ABTS scavenging ability. The ABTS scavenging ability was determined according to the method described by Re et al. (1999). The ABTS was generated by reacting an ABTS aqueous solution $(7 \mathrm{mM} / \mathrm{L})$ with potassium persulphate $\left(\mathrm{K}_{2} \mathrm{~S}_{2} \mathrm{O}_{8}\right)(2.45 \mathrm{mM} / \mathrm{L}$, final concentration) in the dark at room temperature for $16 \mathrm{~h}$ and adjusting the absorbance at $734 \mathrm{~nm}$ to 0.700 with ethanol. 0.2 $\mathrm{mL}$ of appropriate dilution of the extract was added to $2.0 \mathrm{~mL}$ ABTS solution and the absorbance was measured at $734 \mathrm{~nm}$ after $15 \mathrm{~min}$ in the JENWAY uv - visible spectrophotometer. The trolox equivalent antioxidant capacity was subsequently calculated.

Lipid peroxidation assay. Preparation of tissue homogenates. The rats (12 weeks old and weighing between 220 and $240 \mathrm{~g}$ ) were decapitated under mild diethyl ether anaesthesia and the whole brain rapidly isolated and placed on ice and weighed. This tissue was subsequently homogenized in cold saline $(1: 10, \mathrm{w} / \mathrm{v})$ with about 10 up and down strokes at approximately $1200 \mathrm{rpm}$ in a Teflon glass homogenizer. The homogenate was centrifuged for 10 mins at $3000 \times \mathrm{g}$ to yield a pellet that was discarded, and a low - speed supernatant (SI) which was kept for lipid peroxidation assay (Belle et al., 2004).

Lipid peroxidation and TBA reactions. The lipid peroxidation assay was carried out using the modified method of Ohkawa et al. (1979). Briefly, $100 \mu \mathrm{L}$ SI fraction was mixed with a reaction mixture containing $30 \mu \mathrm{L}$ of $0.1 \mathrm{M}$ Tris- $\mathrm{HCl}$ buffer ( $\mathrm{pH} 7.4$ ), the extract $(0-100 \mu \mathrm{L})$ and $30 \mu \mathrm{L}$ of $250 \mu \mathrm{M}$ freshly prepared $\mathrm{FeSO}_{4}$. The volume was made up to $300 \mu \mathrm{L}$ by water before incubation at $37^{\circ} \mathrm{C}$ for $1 \mathrm{~h}$. The colour reaction was developed by adding $300 \mu \mathrm{L}$ of $8.1 \%$ sodium dodecyl sulphate (SDS) to the reaction mixture containing SI; this was subsequently followed by the addition of $600 \mu \mathrm{L}$ acetic acid/ $\mathrm{HCl}(\mathrm{pH} 3.4)$ mixture and $600 \mu \mathrm{L}$ of $0.8 \%$ thiobarbituric acid (TBA). This mixture was incubated at $100^{\circ} \mathrm{C}$ for $1 \mathrm{~h}$. Thiobarbituric acid reactive species (TBARS) produced were measured at $532 \mathrm{~nm}$ in the JENWAY UV-visible spectrophotometer and the absorbance was compared with that of standard curve using malondialdehyde (MDA). 
Statistical analysis. The results of the three replicates were pooled and expressed as mean \pm standard deviation. Standard deviations were calculated using spread sheet software (Microsoft ExcelC, version 2013). Analysis of variance (ANOVA) was performed using Statistical Analysis System proprietary software (SAS, 2002). Duncan's multiple range test procedure as described in the SAS software was used for mean separations. Significance was accepted at $\mathrm{P}=0.05$. $\mathrm{IC}_{50}$ (extract concentration causing $50 \%$ inhibition of antioxidant activity) was calculated using the linear regression analysis.

\section{Results and Discussion}

Ascorbic acid. The ascorbic acid, total phenol and flavonoid contents of the extract of pawpaw seed are presented in Table 1. The ascorbic acid content of the extract ranged from $27.14 \mathrm{mg}$ ascorbic acid equivalent (AAE/100 g) wet freshly harvested sample (WFHS) to $37.14 \mathrm{mg}$ AAE/100g wet stored sample (WSS). The value of ascorbic acid reported in this work was higher than that reported for papaya seed but lower to the ascorbic acid of papaya pulp and peel (Maisarah et al., 2014; Santos et al., 2014; Nwofia et al., 2012). The result showed that the ascorbic acid content of wet sample extracts (WFHS and WSS) was significantly higher than the corresponding dry sample extracts (DFHS and DSS). This could be because ascorbic acid is easily destroyed by heat. The ascorbic acid content of the seed of stored pawpaw fruit in both wet and dry samples was significantly higher than the seed of freshly harvested fruit. The high ascorbic acid content of the seed of stored pawpaw fruit could be as a result of ripening since the pawpaw fruit stored at room temperature has ripened more than the freshly harvested pawpaw fruit. Ripening has been observed to cause increase in vitamin $\mathrm{C}$ content of guava and mango (Ortega et al., 2013; Gull et al., 2012). The increase in ascorbic acid contents of the seed of stored pawpaw fruit as a result of ripening may be due to physiological activities that persist after harvesting of the fruit which is the breakdown of starch to glucose and this causes increase in the biosynthesis of ascorbic acid. The increase in ascorbic acid content during ripening has also been attributed to the increase in lipid peroxidation which is another physiological activity going on in the ripened fruit (Jimenez et al., 2002).

Phenolic content. The levels of total phenol content in the seed of the pawpaw fruit varied significantly from
Table 1. Phenol, flavonoid, nonflavonoid and ascorbic acid content of pawpaw seed

\begin{tabular}{lllll}
\hline \hline $\begin{array}{l}\text { Pawpaw } \\
\text { sample }\end{array}$ & $\begin{array}{l}\text { Phenol } \\
(\mathrm{mg} / \mathrm{GAE} / \mathrm{g})\end{array}$ & $\begin{array}{l}\text { Flavonoid } \\
(\mathrm{mg} / \mathrm{QE} / \mathrm{g})\end{array}$ & $\begin{array}{l}\text { Non } \\
\text { flavonoid } \\
(\mathrm{mg} / \mathrm{QE} / \mathrm{g})\end{array}$ & $\begin{array}{l}\text { Ascorbic acid } \\
(\mathrm{mg} / \mathrm{AAE} / \\
100 \mathrm{~g})\end{array}$ \\
\hline WFHS & $25.71 \pm 0.00^{\mathrm{c}}$ & $3.16 \pm 0.00^{\mathrm{d}}$ & $22.55 \pm 2.33^{\mathrm{c}}$ & $35.72 \pm 2.02^{\mathrm{b}}$ \\
DFHS & $34.29 \pm 0.00^{\mathrm{b}}$ & $5.79 \pm 0.00^{\mathrm{b}}$ & $28.50 \pm 1.89^{\mathrm{b}}$ & $27.14 \pm 6.05^{\mathrm{d}}$ \\
WSS & $25.24 \pm 0.67^{\mathrm{c}}$ & $3.95 \pm 0.36^{\mathrm{c}}$ & $21.29 \pm 0.00^{\mathrm{d}}$ & $37.14 \pm 0.00^{\mathrm{a}}$ \\
DSS & $41.43 \pm 0.67^{\mathrm{a}}$ & $7.63 \pm 0.37^{\mathrm{a}}$ & $33.80 \pm 2.17^{\mathrm{a}}$ & $34.29 \pm 0.00^{\mathrm{c}}$ \\
\hline \hline
\end{tabular}

Values represent mean \pm standard deviation of triplicate determination. Values with the same letter along the same column are not significantly different $(\mathrm{P} \leq 0.05)$. GAE $=$ gallic acid equivalent; $\mathrm{AAE}=$ ascorbic acid equivalent; $\mathrm{QE}=$ quercetin equivalent; WFHS = wet freshly harvested sample, DFHS = dry freshly harvested sample, WSS $=$ wet stored sample, DSS = dry stored sample.

25.24 to $41.43 \mathrm{mg}$ gallic acid equivalent (GAE/g). The dry seed of stored pawpaw fruit DSS contained the highest phenolic content (41.43 mg GAE/g), followed by the dry seed of freshly harvested pawpaw fruit DFHS (34.29 mg GAE/g), wet seed of freshly harvested pawpaw fruit WFHS (25.71 mg GAE/g) and wet seed of stored pawpaw fruit WSS (25.24 mg GAE/g). The phenolic content reported in this work was higher than the value reported in previous study for papaya seed on dry weight basis (Maisarah et al., 2014; Santos et al., 2014) but lower to $211.31 \mathrm{~g} \mathrm{GAE} / \mathrm{g}$ and $156.53 \mathrm{~g}$ GAE/g reported for water and hexane extract of papaya seed (Kothari and Seshadri, 2010). The result indicated that the dry seed of pawpaw fruit (DFHS and DSS) contain high phenolic content in both freshly harvested and stored pawpaw fruit, which may provide good sources of dietary antioxidant and gastro protective medicine. The phenolic content of the wet samples of pawpaw seed decreased in storage but not significant. The stored pawpaw fruit has ripened in storage than freshly harvested which could be a factor for the decrease in the phenolic content. The findings of Gull et al. (2012) in ripening stages of guava also showed that there was an apparent gradual decrease in the total phenolic contents during ripening of guava fruit, which might be associated with an amplified polyphenol oxidase activity. Ripening and other physiological activities continue in all plant crops following harvesting. These processes involve changes in the chemical composition and physical characteristics of the plant material and can influence its quality as food, whether it is consumed fresh or used as raw material for subse-quent processing operations (Rhodes, 1980). 
Flavonoid content. The result of Flavonoid in $\mathrm{mg}$ quercetin equivalent $(\mathrm{QE} / \mathrm{g})$ revealed that dry seed of pawpaw fruit at both freshly harvested and stored fruit had a significantly higher flavonoid $(7.63 \mathrm{mg} \mathrm{QE} / \mathrm{g}$ (DSS) and $5.79 \mathrm{mg}$ QE/g (DFHS) content than wet seed of pawpaw fruit (3.95 mg QE/g (WSS) and $3.16 \mathrm{mg}$ $\mathrm{QE} / \mathrm{g}$ (WFHS)). The flavonoid in the present study was within the range of values reported by Kothari and Seshadri (2010) for papaya seed using ethanol and water extraction method 10.20-4.42 mg QE/g but higher than $59.54 \mathrm{mg} / 100 \mathrm{~g}$ reported by Maisarah et al. (2013). There was an increase in the flavonoid content of pawpaw seed due to storage. The basis of the increase could not be categorically stated; though, it may be due to ripening, a physiological activity that releases ethylene, a phytohormone that stimulates the activity of the key enzyme involved in polyphenol biosynthesis, phenylalanine ammonium lyase (PAL), which leads to formation of polyphenols. PAL activity has been shown to have a direct influence on total flavonoids (Matthes and Schmitz-Eiberger, 2009). An increase in polyphenol content during shelf life has been explained to be caused by a higher ethylene production which resulted in a stimulation of PAL (Napolitano et al., 2004). The nonflavonoid content of the pawpaw seed of freshly harvested pawpaw fruit and stored pawpaw fruit followed the same observation for both the total phenol and flavonoid contents where the values for the dry seeds of pawpaw fruit were significantly higher than others in the order of DSS $>$ DFHS $>$ WFHS $>$ WSS (Table 1).

In complex systems, like food and food preparations, there are different mechanisms that may contribute to oxidative processes, in some mechanism, transition metal ions play a vital role, where different ROS may be generated and molecules like lipids, proteins and carbohydrates may be affected, while in another mechanism the ability of the extracts to donate electrons or the ability to protect carbohydrate structures or the ability to chelate $\mathrm{Fe}^{2+}$ is tested (Hinneburg et al., 2006; Halliwell, 1997). Several food components like carotenoids, vitamin $\mathrm{C}$ and $\mathrm{E}$, polyphenolic compounds and the synergisms among them contribute to the overall antioxidant ability of food, it will then be difficult to assess total antioxidant ability on the basis of these individual active components alone (Pinelo et al., 2004). It is on this premise that ferric reducing antioxidant power (FRAP), iron chelating activity, 1,1-diphenyl-2 picrylhydrazyl (DPPH) radical scavenging abilities, 2,2-azinobis-3-ethylbenzo-thiazoline-6-sulphonate (ABTS), lipid peroxidation and thiobarbibutric acid reactions (TBARS) were evaluated for the measurement of total antioxidant activity of pawpaw seed in both freshly harvested and stored pawpaw fruit.

Ferric reducing antioxidant power (FRAP). Iron (III) ion $\mathrm{Fe}^{3+}$ reduction has been used many times as an indicator of electron- donating activity, which is an important mechanism of phenolic antioxidant action (Hinneburg et al., 2006). The $\mathrm{Fe}^{3+}$ to $\mathrm{Fe}^{2+}$ reducing activity of the pawpaw seed is expressed as $\mathrm{mg}$ Ascorbic Acid Equivalents AAE/g sample. Figure 1 shows that all the extracts have the ability to reduce $\mathrm{Fe}^{3+}$ to $\mathrm{Fe}^{2+}$. The best activity was found in dry seed of stored pawpaw fruit DSS (14.28 mg AAE/g) which was significantly higher than the other extracts. There was no significant difference in the FRAP activity of the wet seed extract of freshly harvested pawpaw fruit WFHS and wet seed extract of stored pawpaw fruit WSS, the wet seed extracts performed significantly lower than the dry seed extracts in both the freshly harvested and stored pawpaw fruit. The reducing power of pawpaw seed extracts from the FRAP results demonstrated a potential antioxidant activity in consumer's body. Such a remarkable high reducing power in the dry seed of stored pawpaw fruit (DSS) was attributed to their high phenolic and flavonoid content. FRAP assay has been considered to be a good

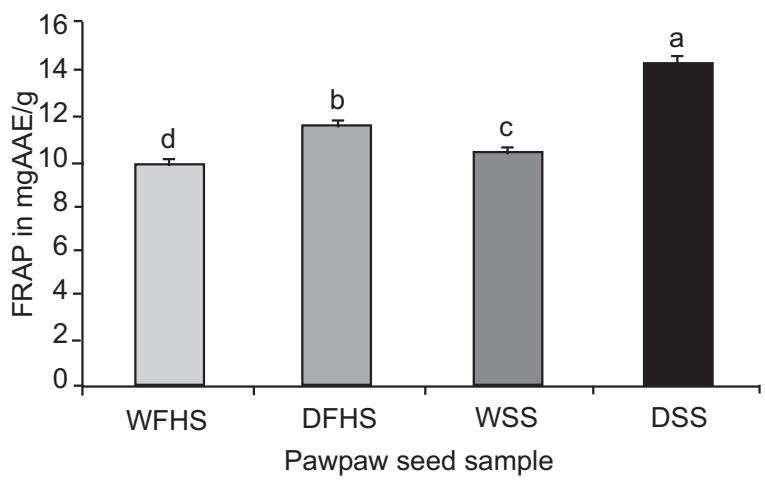

Fig. 1. Ferric reducing antioxidant property (FRAP) of pawpaw seed.

Values represent mean \pm standard deviation of triplicate determination. Values with the same letter are not significantly different $(\mathrm{P} \leq 0.05)$. AAE - Ascorbic Acid. WFHS $=$ wet freshly harvested sample, DFHS = dry freshly harvested sample, WSS = wet stored sample, DSS = dry stored sample. 
method in evaluating the antioxidant capacity of fruits (Palafox-Carlos et al., 2012). However, it was discovered that FRAP have some disadvantages in that any electrondonating substances with redox potential lower than that of the redox pair $\mathrm{Fe}^{3+} / \mathrm{Fe}^{2+}$ can contribute to the FRAP value and indicate a false high values of FRAP even if they don't have antioxidant properties (Nilsson et al., 2005).

Iron chelation. Foods are always contaminated with transition metal ions and these may be introduced by processing methods. Bivalent transition metal ions have a crucial role to play as catalysts of oxidative processes, leading to the formation of hydroxyl radicals and hydroperoxide decomposition reactions via Fenton chemistry (Halliwell, 1997). These can be prevented by iron chelation and deactivation. Therefore, the ability of the extracts of the pawpaw seed to chelate $\mathrm{Fe}^{2+}$ ions was evaluated and results are presented in Table 2 . The seed of stored pawpaw fruit in the dry sample (DSS) and wet sample (WSS) showed the best iron chelating ability of $25.65 \%$, respectively, which was significantly higher than others; it was closely followed by the dry seed of freshly harvested pawpaw fruit $(24.36 \%)$. The basis for the high chelating ability of WSS $25.65 \%$ could not be categorically stated; however, it is expected that DSS would have a high chelation activity because of its high phenolic and flavonoid content which has been positively correlated to the iron chelation activity of food (Al-Farga et al., 2014; Hinneburg et al., 2006).

The DPPH. The DPPH results were used to confirm the results obtained in total phenolic content (PalafoxCarlosa et al., 2012). DPPH radical-scavenging ability

Table 2. $\mathrm{Fe}^{2+}$ chelation, ABTS, $\mathrm{IC}_{50}$ of DPPH and lipid peroxidation of pawpaw seed

\begin{tabular}{|c|c|c|c|c|}
\hline $\begin{array}{l}\text { Pawpaw } \\
\text { sample }\end{array}$ & $\begin{array}{l}\mathrm{Fe}^{2+} \\
\text { chelation } \\
(\%)\end{array}$ & $\begin{array}{l}\text { ABTS } \\
(\mathrm{mmol} \text {.TEAC/ } \\
100 \mathrm{~g})\end{array}$ & $\begin{array}{l}\text { DPPH } \\
\mathrm{IC}_{50}(\mathrm{mg} / \\
\mathrm{mL})\end{array}$ & $\begin{array}{l}\text { Lipid peroxi- } \\
\text { dation } \\
\mathrm{IC}_{50}(\mathrm{mg} / \mathrm{mL})\end{array}$ \\
\hline WFHS & $21.80 \pm 5.43^{\mathrm{c}}$ & $2.08 \pm 0.27^{\mathrm{c}}$ & $33.66 \pm 4.12^{\mathrm{b}}$ & $11.28 \pm 1.00^{\mathrm{a}}$ \\
\hline DFHS & $24.36 \pm 1.81^{\mathrm{b}}$ & $7.17 \pm 0.53^{\mathrm{a}}$ & $15.36 \pm 1.81^{\mathrm{d}}$ & $4.5 \pm 0.00^{\mathrm{d}}$ \\
\hline WSS & $25.65 \pm 3.62^{\mathrm{a}}$ & $0.94 \pm 0.26^{\mathrm{d}}$ & $38.60 \pm 3.76^{\mathrm{a}}$ & $6.53 \pm 0.64^{\mathrm{b}}$ \\
\hline DSS & $25.65 \pm 3.63^{\mathrm{a}}$ & $6.04 \pm 0.53^{\mathrm{b}}$ & $15.08 \pm 1.67^{\mathrm{c}}$ & $5.68 \pm 0.63^{\mathrm{c}}$ \\
\hline
\end{tabular}

Values represent mean \pm standard deviation of triplicate determination. Values with the same letter along the same column are not significantly different $(\mathrm{P} \leq 0.05)$. TEAC $=$ trolox equivalent antioxidant capacity; WFHS = wet freshly harvested sample; DFHS = dry freshly harvested sample; WSS $=$ wet stored sample; DSS = dry stored sample. of the pawpaw seed at $0-33.33 \mathrm{mg} / \mathrm{mL}$ concentrations was measured and the results are presented in Fig. 2. A dose-response relationship was found in the DPPH radical-scavenging ability of the pawpaw seed extracts; the ability increased significantly with an increase in the concentration of the pawpaw seed extracts. It showed from these results that the dry seed of pawpaw fruit in both freshly harvested and stored pawpaw fruit (DSS and DFHS) recorded the highest DPPH radical-scavenging ability which was significantly higher than the wet seed of pawpaw fruit (WFHS and WSS). It can be seen from Table 2 that DSS with the lowest $\mathrm{IC}_{50}(15.08 \mathrm{mg} /$ $\mathrm{mL}$ ) exhibited the highest DPPH radical-scavenging activity, followed by DFHS ( $\mathrm{IC}_{50} 15.36 \mathrm{mg} / \mathrm{mL}$ ). These result suggested that dry pawpaw seed (DSS and DFHS) are competent DPPH radical scavenger. This is an indication that it has the ability to protect consumer's health from various free-radical related diseases including ageing, cancer, atherosclerosis, Alzheimer disease, diabetes and so on.

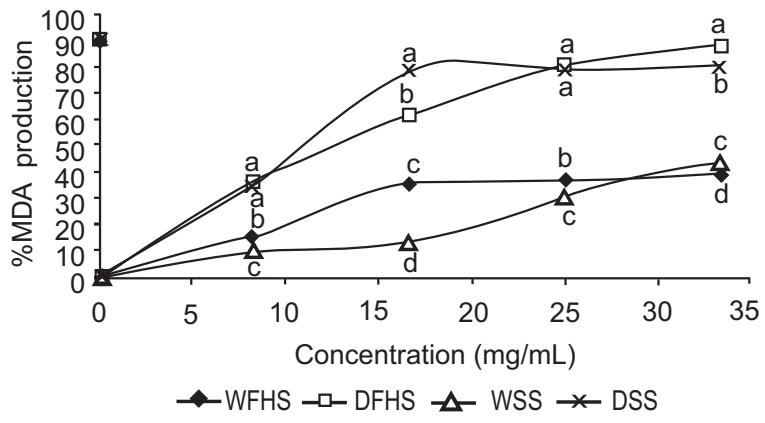

Fig. 2. DPPH scavenging abilities of pawpaw seed. Values represent mean \pm standard deviation of triplicate determination. Values with the same letter along the same column are not significantly different ( $\mathrm{P} \leq 0.05)$. WFHS = wet freshly harvested sample, DFHS = dry freshly harvested sample, WSS = wet stored sample, DSS = dry stored sample.

The ABTS. The ABTS radical has been used to confirm results obtained with DPPH, because both possess similar antioxidant mechanisms. The versatility of ABTS radical scavenging ability is an advantage since it can measure both non-polar and polar antioxidants and spectral interference is minimized as the absorption maximum used is $760 \mathrm{~nm}$, a wavelength not normally encountered with natural products (Perez-Jimenez et al., 2008; Re et al., 1999). 
ABTS scavenging ability reported as trolox equivalent antioxidant capacity (TEAC) of the pawpaw seed of freshly harvested pawpaw fruit and stored pawpaw fruit is presented in Table 2. The result revealed that the ABTS scavenging ability of dry seed of freshly harvested pawpaw fruit DFHS $7.17 \mathrm{mmol}$. TEAC/100 g was significantly higher than other samples, closely followed by the dry seed of stored pawpaw fruit DSS $6.04 \mathrm{mmol}$. $\mathrm{TEAC} / 100 \mathrm{~g}$. The higher the TEAC value of the sample, the stronger the antioxidant activity (Zarena and Sankar, 2009). It is to be noted that high antioxidant activities in extracts may be attributed to the phenolic and flavonoid content of the extract, it was expected considering the high phenolic and flavonoid content of the extract of dry seed of stored pawpaw fruit (DSS) to have the highest ABTS scavenging ability but contrary is the case in this work where ABTS scavenging ability observed do not follow the order of phenolic and flavonoid content.

Lipid peroxidation. The polyunsaturated fatty acids (PUFAs) rich phospholipids in the brain membranes are easily attacked by free radicals, causing oxidative damage to the brain phospholipids which could result to the development of Alzhemier's disease (Axelsen et al., 2011). The protective capacity of the pawpaw seed extracts against $\mathrm{Fe}^{2+}$ induced lipid peroxidation in cultured rat brain, is shown in Fig. 3. Incubation of rat's brain in the presence of $250 \mu \mathrm{M}$ iron (II) caused a significant increase in the malondialdehyde (MDA) content of the brain (180\%). The increase in iron in this organ resulted in the formation of reactive oxygen species ROS which facilitates lipid peroxidation through Fenton reaction. This could have accounted for the increase in MDA contents of the brain after incubation in the presence of $\mathrm{Fe}^{2+}$. The result showed that the aqueous extracts of pawpaw seed significantly inhibited MDA production in the brain in a dose dependent manner. The dry seed of freshly harvested pawpaw fruit and stored pawpaw fruit had the highest inhibitory effect on the $\mathrm{Fe}^{2+}$ induced lipid peroxidation in rat brain since they exhibited the least $\mathrm{IC}_{50} 4.05 \mathrm{mg} / \mathrm{mL}$ DFHS and $5.68 \mathrm{mg} / \mathrm{mL}$ DSS (Table 2). The lipid peroxidation inhibition in this work followed the trend observed for ABTS scavenging ability where the scavenging ability of the dry seed of freshly harvested pawpaw fruit (DFHS) was significantly higher than other samples, closely followed by the dry seed of stored pawpaw fruit (DSS). The possible mechanism through which the extracts protect the brain could be by $\mathrm{Fe}^{2+}$ chelation and the scavenging of hydroxyl ion (Ademosun and
Oboh, 2014). The ability of pawpaw seed extracts to inhibit $\mathrm{Fe}^{2+}$ induced lipid peroxidation in rat brain homogenate in-vitro is a reflection that pawpaw seed extracts could prevent the elevation of brain iron levels which can cause increase in iron transport across the blood brain barrier and resulted to extracellular iron overload of the brain that can lead to neurodegenerative condition of Alzhemier's disease.

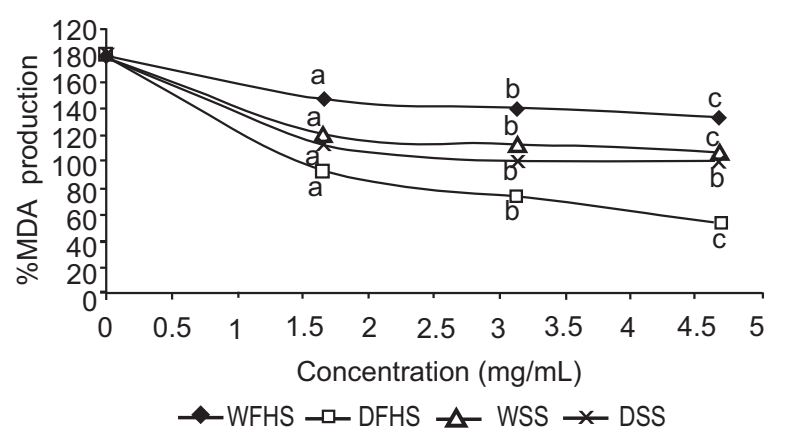

Fig. 3. Inhibition of $\mathrm{Fe}^{2+}$ induced MDA production in rat brain by pawpaw seed extract.

Values represent mean \pm standard deviation of triplicate determination. Values with the same letter along the same column are not significantly different $(\mathrm{P} \leq 0.05)$. WFHS $=$ wet freshly harvested sample, DFHS = dry freshly harvested sample, WSS $=$ wet stored sample, DSS = dry stored sample.

\section{Conclusion}

The total phenol and flavonoid content of pawpaw seed in dry samples increased when pawpaw fruit was stored but storage of pawpaw fruit has no significant effect on the total phenol and flavonoid content of pawpaw seed in wet samples. Storage of pawpaw fruit caused an increase in the ascorbic acid content of pawpaw seed in both wet and dry samples. Storage of pawpaw fruit also caused an increase in the scavenging abilities of dry pawpaw seed since the dry pawpaw seed of stored pawpaw fruit exhibited higher antioxidant activities. The knowledge about the antioxidant composition of the seeds of stored pawpaw fruit when dried provides important information for pharmaceutical and food industries interested in adding value to pawpaw fruit.

\section{References}

Ademosun, A.O., Oboh, G. 2014. Anticholinesterase and antioxidative properties of water - extractable 
phytochemicals from some citrus peels. Journal of Basic and Clinical Physiology and Pharmacology, 25: 199-204.

Adetuyi, F.O., Akinadewo, L.T., Omosuli, S.V., Ajala, L. 2008. Antinutrient and antioxidant quality of waxed and unwaxed pawpaw (Carica papaya) fruit stored at different temperatures. African Journal of Biotechnology, 7: 2920-2924.

Afolabi, I.S., Ofobrukweta, K. 2011. Physicochemical and nutritional qualities of Carica papaya seed products. Journal of Medicinal Plants Research, 5: 3113-3117.

AL-Farga, A., Hui, Z., Azhari, S. 2014. In vitro antioxidant activity and total phenolic and flavonoid contents of Alhydwan (Boerhavia elegana Choisy) Seeds. Journal of Food and Nutrition Research, 2: 215-220.

Amenta, R., Camarda, L., Di-Stefano, V., Lentini, F., Venza, F. 2000. Traditional medicine as a source of new therapeutic agents against psoriasis. Fitoterapia, 71: 13-20.

Ang, Y.K., Sia, W.C.M., Khoo, H.E., Yim, H.S. 2012. Antioxidant potential of Carica Papaya peel and seed. Focusing on Modern Food Industry, 1: 1116.

Axelsen, P.H., Komatsu, H., Murray, I.V.J. 2011. Oxidative stress and cell membranes in the pathogenesis of Alzheimer's disease. Physiology, 26: 54-69.

Benderitter, M., Maupoli, V., Vergely, C., Dalloz, F., Briot, F., Rochette, L. 1998. Studies by electron paramagnetic resonance of the importance of iron in the hydroxyl scavenging properties of ascorbic acid in plasma: Effects of iron chelators. Fundamentals and Clinical Pharmacology, 12: 510-516.

Belle, N.A.V., Dalmolin, G.D., Fonini, G., Rubim, M.A., Rocha, J.B.T. 2004. Polyamines reduces lipid peroxidation induced by different pro-oxidant agents. Brain Research, 1008: 245-251.

Bolu, S.A.O., Sola-Ojo, F.E., Olorunsanya, O.A., Idris, K. 2009. Effect of graded levels of dried pawpaw (Carica papaya) seed on the performance, haematology, serum biochemistry and carcass evaluation of chicken broilers. International Journal of Poultry Science, 8: 905-909.

Gull, J., Sultana, B., Anwar, F., Naseer, R., Ashraf, M., Ashrafuzzaman, M. 2012. Variation in antioxidant attributes at three ripening stages of guava (Psidium guajava L.) fruit from different geographical regions of Pakistan. Molecules, 17: 3165-3180.

Halliwell, B. 1997. Antioxidants: the basics - what they are and how to evaluate them. Advances in Pharmacology, 38: 3-20.

Hana, U.B., Angelo, P.J. 2006. Ripening and quality of 'Golden' papaya fruit harvested at different maturity stages. Brazilian Journal of Plant Physiology, 18: 389-396.

Hinneburg, I., Damien Dorman, H.J., Hiltunen, R. 2006. Antioxidant activities of extracts from selected culinary herbs and spices. Food Chemistry, 97: 122-129.

Jimenez, A., Cressen, G., Kular, B., Firmin, J., Robinson, S., Verhoeyen, M., Phil, M. 2002. Changes in oxidative process and components of the antioxidant system during tomato fruit ripening. Journal of Planta, 214: 751-758.

Kothari, V., Seshadri, S. 2010. Antioxidant activity of seed extracts of Annona squamosa and Carica papaya. Nutrition and Food Science, 40: 403-408.

Krishna, K.L., Paridhavi, M., Jagruti , A.P. 2008. Review on nutritional, medicinal and pharmacological properties of papaya (Carica papaya Linn.). Indian Journal of Natural Products and Resources, 7: 364-373.

Kuda, T., Tsunekawa, M., Goto, H., Araki, Y. 2005. Antioxidant properties of four edible algae harvested in the Noto Peninsula, Japan. Journal of Food Composition and Analysis, 18: 625-633.

Maisarah, A.M., Asmah, R., Fauziah, O. 2014. Proximate analysis, antioxidant and antiproliferative activities of different parts of Carica papaya. Journal of Nutrition and Food Science, 4: 2-7.

Maisarah, A.M., Nurul Amira, B., Asmah, R., Fauziah, O. 2013. Antioxidant analysis of different parts of Carica papaya. International Food Research Journal, 20: 1043-1048.

Malacrida, C.R., Kimura, M. Jorge, N. 2011. Characterization of a high oleic oil extracted from papaya (Carica papaya L.) seeds. Ciencia Tecnologia Aliments, 31: 929-934.

Matthes, A., Schmitz-Eiberger, M. 2009. Polyphenol content and antioxidant capacity of apple fruit: effect of cultivar and storage conditions. Journal of Applied Botany and Food Quality, 82: 152-157.

Meda, A., Lamien, C.E., Romito, M., Millogo, J., Nacoulma, O.G. 2005. Determination of the total phenolic, flavonoid and proline contents in Burkina Fasan honey, as well as their radical scavenging activity. Food Chemistry, 91: 571-577.

Napolitano, A., Cascone, A., Graziani, G., Ferracane, R., Scalfi, L., Di Vaio, C., Ritieni, A., Fogliano, V. 2004. Influence of variety and storage on the 
polyphenol composition of apple flesh. Journal of Agricultural and Food Chemistry, 52: 6526-6531.

Nilsson, J., Pillai, D., Onning, G., Persson, C., Nilsson, Å., Åkesson, B. 2005. Comparison of the 2,2azinobis-3-ethylbenzotiazo-line-6-sulfonic acid (ABTS) and ferric reducing anti-oxidant power (FRAP) methods to assess the total antioxidant capacity in extracts of fruit and vegetables. Molecular Nutrition and Food Research, 49: 239246.

Nwofia, G.E., Ojimelukwe, P., Eji, C. 2012. Chemical composition of leaves, fruit pulp and seeds in some Carica papaya (L.) morphotypes. International Journal of Medicine and Aromatic Plants, 2: 200206.

Oboh, G., Ademiluyi, A.O., Akindahunsi, A.A. 2010. The effect of roasting on the nutritional and antioxidant properties of yellow and white maize varieties. International Journal of Food Science and Technology, 45: 1236-1242.

Ohkawa, H., Ohishi, N., Yagi, K. 1979. Assay for lipid peroxides in animal tissues by thiobarbituric acid reaction. Analytical Biochemistry, 95: 351-358.

Okeniyi, J.A., Ogunlesi, T.A., Oyelami, O.A., Adeyemi, L.A. 2007. Effectiveness of dried Carica papaya seeds against human intestinal parasitosis: A pilot study. Journal of Medicinal Food, 10: 194-196.

Okewumi, T.A., Oyeyemi, A.W. 2012. Gastro-protective activity of aqueous Carica papaya seed extract on ethanol induced gastric ulcer in male rats. African Journal of Biotechnology, 11: 8612-8615.

Ortega, V.G., Ramírez, J.A., Velázquez, G., Tovar, B., Mata, M., Montalvo, E. 2013. Effect of high hydrostatic pressure on antioxidant content of 'Ataulfo' mango during postharvest maturation. Food Science and Technology (Campinas), 33: 561-568.

Oyaizu, M. 1986. Studies on products of browning reaction: Antioxidative activity of products of browning reaction prepared from glucosamine. Japanese Journal of Nutrition and Dietetics, 44: 307-315.

Oyeleke, G.O., Isola, A.D., Salam, M.A., Ajao, F.D. 2013. Evaluation of some chemical composition of pawpaw (Carica papaya) seeds under normal storage ripening. Journal of Environmental Science, Toxicology and Food Technology (IOSR-JESTFT) 4: 18-21.

Palafox-Carlos, H., Yahia, E., Islas-Osuna, M.A., Gutierrez-Martinez, P., Robles-Sánchez, M.,
González-Aguilar, G.A. 2012. Effect of ripeness stage of mango fruit (Mangifera indica L., cv. Ataulfo) on physiological parameters and antioxidant activity. Scientia Horticulturae, 135: 7-13.

Perez-Jimenez, J.A., Arranz, S., Tabernero, M., DiazRubio, M.E., Serrano, J., Goni, I., Saura-Calixto, F. 2008. Updated methodology to determine antioxidant capacity in plant foods, oils and beverages: Extraction, measurement and expression of results. Food Research International, 41: 274285.

Pinelo, M., Manzocco, L., Nunez, M.J., Nicoli, M.C. 2004. Interaction among phenols in food fortification: negative synergism on antioxidant capacity. Journal of Agricultural and Food Chemistry, 52: 1177-1180.

Re, R., Pellegrini, N., Proteggente, A., Pannala, A., Yang, M., Rice-Evans, C. 1999. Antioxidant activity applying an improved ABTS radical cation decolorization assay. Free Radical Biology and Medicine, 26: 1231-1237.

Rhodes, M.J.C. 1980. The physiological basis for the conservation of food crops. Progress in Food and Nutrition Science, 4: 11-20.

SAS, 2002. Statistical Analysis System Proprietary software. Release 8.3. SAS Institute Inc., Carry, NC, USA.

Santos, C.M., Abreu, C.M.P., Freire, J.M., Queiroz, E.R., Mendonça, M.M. 2014. Chemical characterization of the flour of peel and seed from two papaya cultivars. Food Science and Technology (Campinas), 34: 353-357.

Saran, P.L., Choudhary, R. 2013. Drug bioavailability and traditional medicaments of commercially available papaya: A review. African Journal of Agricultural Research, 8: 3216-3223.

Singh, R.P., Murthy, C.K.N., Jayaprakasha, G.K. 2002. Studies on the antioxidant activity of pomegranate (Punica granatum) peel and seed extracts using in vitro methods. Journal of Agricultural and Food Chemistry, 50: 81-86.

Singleton, V.L., Orthofer, R., Lamuela-Raventos, R.M. 1999. Analysis of total phenols and other oxidation substrates and antioxidants by means of FolinCioalteau Reagent. Book Series: Methods in Enzymology, 299C: 152-178.

Zarena, A.S., Sankar, K.U. 2009. A study of antioxidant properties from Garcinia mangostana L. pericarp extract. Acta Scientiarum Polonorum, Technologia Alimentaria, 8: 23-34. 